\title{
Identification of Adoption Gap and Constraints Faced by the Pineapple Growers in the Selected Districts of Tripura
}

\author{
Rajib Das ${ }^{1}$, Kaushal Kumar Jha ${ }^{2}$, Abhishek $\mathrm{Sen}^{3}$ and Siraj Miah ${ }^{4 *}$ \\ ${ }^{1}$ Krishi Vigyan Kendra, Khowai, Tripura - 797207, India \\ ${ }^{2}$ Department of Agricultural Extension, SASRD; Nagaland University, \\ Medziphema, Dimapur, Nagaland - 797106, India \\ ${ }^{3}$ Uttar Banga Krishi Viswavidyalaya, Cooch Behar, West Bengal- 736165, India \\ ${ }^{4}$ School of Agricultural Sciences and Rural Development, Nagaland University, Nagaland- \\ 797106, India \\ *Corresponding author
}

\section{A B S T R A C T}

\section{Keywords}

Pineapple,

Adoption,

Recommended

practices,

Constraints, Tripura

Article Info

Accepted:

24 August 2019

Available Online:

10 September 2019
Tripura is one of smallest state among the Indian states. Having a very limited area, Tripura has got a diverse agro-climatic conditions which highly suitable to grow various horticultural crops. Pineapple fruit is widely grown in Tripura and is the fifth leading pineapple producing state of India. So many farmers were directly depends on pineapple for their livelihood years back. But since from few years back the production level of pineapple in Tripura was gradually decreasing and also area under pineapple was shrinking regularly. State horticulture department has implemented many policies to uplift the production level and they go success but not as much as they expected. Therefore a study was planned to know the adoption level of recommended package of practices and various constraints faced by the pineapple growers in two selected districts namely Dhalai and Khowai on the basis of highest and lowest production. Results revealed from the study were that majority $(39.58 \%)$ of the pineapple growers fully adopted certain recommended practices, i.e grading the pineapple fruit. Further 81.25 per cent of them partially adopted the recommended practices of climate and soil, while 97.92 per cent respondents didn't adopt the practices like curing of planting material, chemical induction of flowering, proper method of chemical application and insect pest and disease management practices.

\section{Introduction}

The pineapple (Ananas sativus syn. Ananas comosus Merr.) is one of the most important commercial tropical fruits of the world. India has made a good progress on the horticultural produce in world level with a total annual production of 2038.44 thousand MT (2016-17) from 121.09 thousand ha and the growth trends increased 5.94 per cent in terms of 
production in 2016-17 over 2015-16 (Anonymous, 2017). Pineapple is a wellpositioned fruit since its trade is oriented towards developed countries such as Japan, the USA and the European Community. The pineapple is the third most important tropical fruit crop after banana and citrus (Hassan et al., 2012), contributing to over 20 per cent of the world production of tropical fruits. In countries producing the pineapple, nearly 70 per cent is consumed as fresh fruit. Thailand is the largest producer of pineapple, accounting for 13 per cent of global output, followed by Brazil and Costa Rica (Baruwa, 2013).

Pineapple is one of the most important commercial tropical fruits of the world. India produced 92846 thousand MT of fruits from 6480 thousand ha (Anonymous, 2017). India has wide range of climatic condition and which favours for growing various kinds of horticultural crops like fruits, vegetables, flowers, nuts, spices and plantation crops. With the focused attention given to horticulture, there has been spectacular change in terms of adoption of new technologies, production and availability of horticulture product. India ranks $6^{\text {th }}$ in pineapple production in the world produce around 1736739 MT (2013-14) and which covers 7.40 per cent of world's pineapple production. In India cultivation of pineapple is being carried out since very early times in states like Assam, Kerala, Tamil Nadu, Karnataka, Goa, Pondicherry, Andhra Pradesh, Maharashtra, Tripura, West Bengal and other parts of North East India.

North eastern states have vast potentiality for growing pineapple cultivation owing to the fertile soil and conducive agro-climatic conditions. Among the states of north east India Assam is leading in terms of area and production and Tripura is just behind the Assam both in terms of area and production. Tripura produces 178.45 thousand MT from
12.57 thousand ha area (Anonymous, 2017), which is India's fifth leading state of in pineapple production and Tripura is also share 9.30 per cent of India's total pineapple production. The low input requirement and the remunerative returns have motivated the farmers to adopt more of their horticultural lands under pineapple cultivation. For the development of the socio-economic status of the people and proper utilization of the land which is appropriate for pineapple cultivation, different organization, especially Department of Agriculture, Govt. of Tripura and the Central Govt. jointly implemented various Agricultural and Horticultural programmes. Popularization of pineapple cultivation is one of them. Keeping in view the vast potential and importance of pineapple cultivation to the state's revenue in the broader sense and the impact of the practice on improving the social life of the farmer, this study was undertaken. Through the different efforts by the different government organization in terms of technology generation and diffusion, the pineapple growers of Tripura have adopted so many technologies and they are able to achieve a good production. But it has been observed that the production and productivity have not been reached to the expectation of both the researcher and the grower. As because we assume that there is no gap between technology recommendation by the researchers and technology adoption by the pineapple growers.

\section{Materials and Methods}

The present study was carried out in the state of Tripura. One leading pineapple producing district namely Dhalai and one lowest pineapple producing district namely Khowai district was selected purposively to carry out the present study. From each of the selected districts one RD block namely Ambassa from Dhalai district and Teliamura RD block from Khowai district was selected purposively. 
From each of the selected RD blocks one village was selected randomly and from each village and 72 respondents was selected to make a sample size of 144 . Interview schedule consisting of structured questions was constructed to achieve the objective formulated for the present study. Primary data were collected by using personal interview method from the locality and secondary data were collected from journals, books, articles etc.

\section{Results and Discussion}

\section{Socio-economic, personal and psychological behaviour}

It was revealed from Table 1 that majority $(72.92 \%)$ of the Pineapple growers belonged to middle age group (35-50 years). These finding were in accordance with the findings of Wase (2001), Kafle and Shah (2012) andChavai et al., (2015). Majority (79.17 \%) of the pineapple growers belonged to Scheduled tribe caste. 31.25 per cent of Pineapple growers had education up to secondary school. These findings were in accordance with the findings of Arneja et al., (2009), Chavai et al., (2015). Majority $(54.17 \%)$ of them had nuclear family and remaining 45.83 per cent of them had joint family. These findings were in accordance with the findings of Singh et al., (2014). Majority $(79.17 \%)$ Pineapple farmers had medium family size. These findings were in accordance with the findings of Jha (2012), Boruah et al., (2015) and Kulkarni and Jahagirdar (2015).It also found that majority (37.50\%) of the Pineapple famers belonged to the semi medium land holding category, i.e 24 ha. These findings were in accordance with the findings of Jaisawal et al., (2013). Majority $(77.08 \%)$ of the Pineapple growers possessed low level of social participation, these findings were in accordance with the findings of Jaisawal et al., (2013). 87.50 per cent of the Pineapple farmers had income below Rs. 30,000 from Pineapple cultivation. These findings were similar to the findings of Kulkarni and Jahagirdar (2015). Majority $(89.58 \%)$ of Pineapple growers had medium level of extension contact. These findings were in line with the findings of Singh (2014).66.67 per cent of the pineapple growers had medium level of information sources utilization. These findings were in accordance with the findings of Suresh (2004) and Nagesh (2006).

Adoption of recommended package of practices by the Pineapple growers $N=144$

Table 2 revealed about the extent of adoption of recommended package of practices by the pineapple growers. It was found that 39.58 per cent of the pineapple growers fully adopted the recommended practices of grading the pineapple fruit. Further 81.25 per cent of them partially adopted the recommendations of climate and soil, while 97.92 per cent respondents didn't adopt the practices like curing of planting material, chemical induction of flowering, proper method of chemical application and insect pest and disease management practices.

Constraints faced by the farmers in adoption of improved cultivation and management practices of horticultural crops $\mathrm{N}=144$

The perusal of data given in Table 3 and Fig 1 it was also found that 89.58 per cent of them faced major production constraints which include high incidence of pest and diseases. These findings were in accordance with the findings of Kotnala and Dubey (2013). Majority 72.92 per cent of the horticultural farmers faced problem related to suitable postharvest storage facility. These findings were in similar to the findings of Lal et al., (2011). Majority $(52.08 \%)$ of the Pineapple farmers 
faced problems in unavailability of proper planting materials. These findings were in similar with the findings of Nath and Biswas (2011). Further, it was also found that 31.25 per cent of the Pineapple farmers didn't get any help from extension personnel during crop production. These findings were similar to the findings of Nath and Biswas (2011). In case of technical constraints, 10.42 per cent of the Pineapple farmers faced problems in terms of unavailability of inputs like plant protection chemicals, proper seed materials and weedicides etc. This finding was in accordance with the findings of Biswas and Nath (2013). It was found that 4.16 per cent of the farmers faced problems like water scarcity during summer, electricity problem etc. These findings were similar to the findings of Lal et al., (2011). It was found that, 2.08 per cent of them faced problem in terms of lack of technical knowledge during crop production. Lack of technical knowledge might be due to the less social participation and less training exposure. These findings were similar to the findings of Nath and Biswas (2011). It was also found that out of different economical constraints 2.08 per cent of them faced problem in getting adequate loan facility. These findings were similar to the findings of Nath and Biswas (2011).

Majority of the Pineapple growers belonged to middle age group and this might be due to the fact that farmers belonging to the medium age group had relatively higher experience \& greater level of motivation towards potato farming to sustain their livelihood. Majority of the farmers belonged to scheduled tribe category. It was because pineapples are grown in the hilly areas of Tripura and most of the farmers in this region are tribal. Most of the Pineapple growers had education up to secondary school. Adequate literacy level might have helped the farmers to adopt the recommended practices. Nuclear family type found highest. These days nuclear family has become very common in these areas. Majority of the Pineapple farmers had medium family size. This might be because of the farmer's awareness about the benefits of small family. Most of them are semi medium land holder. Further, majority of the farmers possessed low level of social participation. Most of Pineapple farmers had income below Rs. 30000 from Pineapple cultivation. Most of them had medium level of extension contact might be due to the less intensive extension activities in the concerned area as well as less participation of farmers in the extension activities which might have restricted their gain of required information related to their farming practices. They had medium level of information sources utilization. This might be due to less perceived utility of the concerned information sources.

Majority of pineapple growers fully adopted the recommended practices of grading the pineapple fruit. Majority of them had production constraints which include high incidence of pest and diseases. It was because of lack of knowledge about plant protection measures and moreover government agencies were least involved to solve the problems faced by farmers. Majority of the Pineapple faced problem in storage and it was due to the lack of proper storage infrastructures at the village level and inadequate storage facility. Unavailability of planting material was one of major important constraints and which can minimize by providing suitable planting material by the government agencies or private agencies. Further, it was found that Pineapple farmers did not get help from extension personnel during crop production.

This might be due to low level of contact with the extension personnel and less favourable attitude. In case of technical constraints, unavailability of inputs like plant protection chemicals, proper seed materials and weedicides and this might be due to the reason that the government agencies were not providing the required input materials. 
Table.1 Socio-economic and Personal Characteristics of Pineapple Growers

\begin{tabular}{|c|c|c|c|c|c|}
\hline \multirow{2}{*}{$\begin{array}{l}\text { Sl. } \\
\text { No. }\end{array}$} & \multirow{2}{*}{ Categories } & \multirow{2}{*}{\multicolumn{2}{|c|}{ 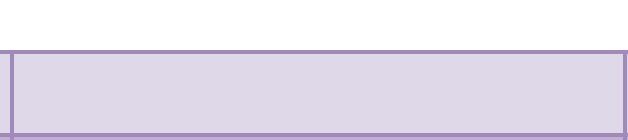 }} & \multicolumn{2}{|l|}{ 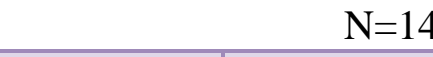 } \\
\hline & & & & Frequency & Percentage \\
\hline & $\begin{array}{l}\text { Distribution of respondents } \\
\text { according to Age }\end{array}$ & & $\begin{array}{l}\text { Below } 35 \text { year } \\
35-50 \text { year } \\
\text { Above } 50 \text { year }\end{array}$ & $\begin{array}{l}3 \\
105 \\
36\end{array}$ & $\begin{array}{l}2.08 \\
\mathbf{7 2 . 9 2} \\
25.00\end{array}$ \\
\hline 2. & $\begin{array}{l}\text { Distribution of respondents } \\
\text { according to Caste }\end{array}$ & & $\begin{array}{l}\text { General } \\
\text { Scheduled Caste (SC) } \\
\text { Scheduled Tribe (ST) } \\
\text { Other Backward Caste (OBC) } \\
\text { Most Other Backward Caste }\end{array}$ & $\begin{array}{l}3 \\
9 \\
114 \\
3 \\
15\end{array}$ & $\begin{array}{l}2.08 \\
6.25 \\
79.17 \\
2.08 \\
10.42\end{array}$ \\
\hline 3. & $\begin{array}{l}\text { Distribution of respondents } \\
\text { according to level of } \\
\text { education }\end{array}$ & $\begin{array}{l}\text { i. } \\
\text { ii. } \\
\text { iii. } \\
\text { iv. } \\
\text { v. } \\
\text { vi. }\end{array}$ & $\begin{array}{l}\text { No Education } \\
\text { Primary Education } \\
\text { Upto Middle School } \\
\text { Upto Secondary } \\
\text { Upto Higher Secondary } \\
\text { Graduation \& Above }\end{array}$ & $\begin{array}{l}12 \\
15 \\
33 \\
45 \\
24 \\
\\
15\end{array}$ & $\begin{array}{l}8.33 \\
10.42 \\
22.92 \\
31.25 \\
16.67 \\
\\
10.42\end{array}$ \\
\hline 4. & $\begin{array}{l}\text { Distribution of respondents } \\
\text { based upon family type }\end{array}$ & $\begin{array}{l}\text { i. } \\
\text { ii. }\end{array}$ & $\begin{array}{l}\text { Joint } \\
\text { Nuclear }\end{array}$ & $\begin{array}{l}66 \\
78\end{array}$ & $\begin{array}{l}45.83 \\
\mathbf{5 4 . 1 7}\end{array}$ \\
\hline 5. & $\begin{array}{l}\text { Distribution of respondents } \\
\text { based on family size }\end{array}$ & $\begin{array}{l}\text { i. } \\
\text { ii. } \\
\text { iii. }\end{array}$ & $\begin{array}{l}\text { Small (Less than 4) } \\
\text { Medium (4-8) } \\
\text { Large (More than 8) }\end{array}$ & $\begin{array}{l}3 \\
114 \\
27\end{array}$ & $\begin{array}{l}2.08 \\
79.17 \\
18.75\end{array}$ \\
\hline 6. & $\begin{array}{l}\text { Distribution of } \\
\text { respondents based on LH } \\
\text { Size }\end{array}$ & $\begin{array}{l}\text { i. } \\
\text { ii. } \\
\text { iii. } \\
\text { iv. } \\
\text { v. }\end{array}$ & $\begin{array}{l}\text { Marginal ( }<1 \text { ha }) \\
\text { Small }(1-2 \text { ha }) \\
\text { Semi Medium }(2-4 \text { ha }) \\
\text { Medium (4-10 ha) } \\
\text { Big (> 10 ha) }\end{array}$ & $\begin{array}{l}39 \\
39 \\
54 \\
6 \\
6\end{array}$ & $\begin{array}{l}27.08 \\
27.08 \\
\mathbf{3 7 . 5 0} \\
4.17 \\
4.17\end{array}$ \\
\hline 7. & $\begin{array}{l}\text { Distribution of respondents } \\
\text { based on } \\
\text { participation }\end{array}$ & $\begin{array}{l}\text { i. } \\
\text { ii. } \\
\text { iii. }\end{array}$ & $\begin{array}{l}\text { Low } \\
\text { Medium } \\
\text { High }\end{array}$ & $\begin{array}{l}111 \\
30 \\
3\end{array}$ & $\begin{array}{l}\mathbf{7 7 . 0 8} \\
20.83 \\
2.08\end{array}$ \\
\hline 8. & $\begin{array}{l}\text { Distribution of respondents } \\
\text { based on Annual income } \\
\text { from Pineapple }\end{array}$ & $\begin{array}{l}\text { i. } \\
\text { ii. } \\
\text { iii. } \\
\text { iv. } \\
\text { v. }\end{array}$ & $\begin{array}{l}\text { Below } 30000 \\
30000-70000 \\
70000-110000 \\
110000-150000 \\
\text { Above } 150000\end{array}$ & $\begin{array}{l}126 \\
6 \\
6 \\
6 \\
0\end{array}$ & $\begin{array}{l}87.50 \\
4.17 \\
4.17 \\
4.17 \\
0.00\end{array}$ \\
\hline 9. & Extension Contact & & $\begin{array}{l}\text { Low }(<2) \\
\text { Medium }(2-3) \\
\text { High }(>3)\end{array}$ & $\begin{array}{l}12 \\
129 \\
3\end{array}$ & $\begin{array}{l}8.33 \\
89.58 \\
2.08\end{array}$ \\
\hline 10. & $\begin{array}{lrr}\text { Distribution } & \text { of } & \text { the } \\
\text { respondents } & \text { based on } \\
\text { information } & \text { sources } \\
\text { utilized } & & \end{array}$ & $\begin{array}{l}\text { i. } \\
\text { i. } \\
\text { i. }\end{array}$ & $\begin{array}{l}\text { Low }(<5.50) \\
\text { Medium }(5.50-12.35) \\
\text { High }(>12.35)\end{array}$ & $\begin{array}{l}27 \\
96 \\
21\end{array}$ & $\begin{array}{l}18.75 \\
66.67 \\
18.75\end{array}$ \\
\hline
\end{tabular}


Table.2 Distribution of respondents based on the extent of adoption of the recommended Pineapple cultivation practices

\begin{tabular}{|c|c|c|c|c|}
\hline \multirow{3}{*}{$\begin{array}{l}\text { Sl. } \\
\text { No. }\end{array}$} & \multirow{3}{*}{$\begin{array}{l}\text { Dimensions of recommended } \\
\text { practices }\end{array}$} & \multicolumn{3}{|c|}{ Extent of adoption by farmers } \\
\hline & & \multirow{2}{*}{$\begin{array}{l}\text { No Adoption } \\
\text { No } \\
\%\end{array}$} & \multirow{2}{*}{$\begin{array}{l}\text { Partial } \\
\text { Adoption } \\
\text { No \% }\end{array}$} & \multirow{2}{*}{$\begin{array}{l}\text { Full } \\
\text { Adoption } \\
\text { No \% }\end{array}$} \\
\hline & & & & \\
\hline 1 & $\begin{array}{l}\text { High Density Planting (Spacing- } \\
90 \mathrm{~cm} \times 60 \mathrm{~cm} \times 30 \mathrm{~cm} ; 43500 \text { plants } / \mathrm{ha})\end{array}$ & $\begin{array}{l}120 \\
(83.3 .3)\end{array}$ & $\begin{array}{l}21 \\
(14.58)\end{array}$ & $\begin{array}{l}3 \\
(2.08)\end{array}$ \\
\hline 2 & $\begin{array}{l}\text { Selection of proper planting } \\
\text { materials ( suckers should be } 450 \mathrm{gm} \\
\text { and slips should be } 350 \mathrm{gm} \text { ) }\end{array}$ & $\begin{array}{l}39 \\
(27.08)\end{array}$ & $\begin{array}{l}63 \\
(43.75)\end{array}$ & $\begin{array}{l}42 \\
(29.17)\end{array}$ \\
\hline 3 & $\begin{array}{l}\text { Curing of Planting Materials } \\
\text { (dipping in } 0.3 \% \text { Dithan Z-78 is } \\
\text { desirable for } 5 \text { minutes) }\end{array}$ & $\begin{array}{l}141 \\
(\mathbf{9 7 . 9 2})\end{array}$ & $\begin{array}{l}3 \\
(2.08)\end{array}$ & $\begin{array}{l}0 \\
(0.00)\end{array}$ \\
\hline 4 & $\begin{array}{l}\text { Climate and Soil ( } 18^{0} \mathrm{C} \text { to } 32^{0} \mathrm{C} \text { is } \\
\text { most favourable and required sandy } \\
\text { soil with good drainage facility) }\end{array}$ & $\begin{array}{l}0 \\
(0.00)\end{array}$ & $\begin{array}{l}117 \\
(81.25)\end{array}$ & $\begin{array}{l}27 \\
(18.75)\end{array}$ \\
\hline 5 & $\begin{array}{l}\text { Land Preparation (The land is } \\
\text { generally prepared by hoeing, but in } \\
\text { areas where the slope is not too steep, } \\
\text { the land may be leveled by ploughing) }\end{array}$ & $\begin{array}{l}12 \\
(8.33)\end{array}$ & $\begin{array}{l}105 \\
(72.92)\end{array}$ & $\begin{array}{l}27 \\
(18.75)\end{array}$ \\
\hline 6 & Planting Season (May to June) & $\begin{array}{l}9 \\
(6.25)\end{array}$ & $\begin{array}{l}105 \\
(72.92)\end{array}$ & $\begin{array}{l}30 \\
(20.83)\end{array}$ \\
\hline 7 & $\begin{array}{l}\text { Fertilization }\left(600 \mathrm{~kg} \mathrm{~N}, 400 \mathrm{Kg} \mathrm{P}_{2} \mathrm{O}_{5}\right. \\
\text { and } 600 \mathrm{~kg} \mathrm{~K} \mathrm{~K}_{2} \mathrm{O} \text { with } 25-30 \text { tons of } \\
\text { FYM per ha) }\end{array}$ & $\begin{array}{l}132 \\
(91.67)\end{array}$ & $\begin{array}{l}12 \\
(8.33)\end{array}$ & $\begin{array}{l}0 \\
(0.00)\end{array}$ \\
\hline 8 & $\begin{array}{l}\text { Earthing up ( to keep the plant } \\
\text { upright and removal of slips) }\end{array}$ & $\begin{array}{l}135 \\
(93.75)\end{array}$ & $\begin{array}{l}6 \\
(4.17)\end{array}$ & $\begin{array}{l}3 \\
(2.08)\end{array}$ \\
\hline 9 & $\begin{array}{l}\text { Chemical induction of flowering } \\
\text { (Ethrel } 25 \mathrm{ppm}(6.25 \mathrm{ml} / 100 \text { lts of } \\
\text { water }+2 \% \text { urea }+0.04 \% \text { Sodium } \\
\text { carbonate) }\end{array}$ & $\begin{array}{l}47 \\
(97.92)\end{array}$ & $\begin{array}{l}1 \\
(2.08)\end{array}$ & $\begin{array}{l}0 \\
(0.00)\end{array}$ \\
\hline 10 & $\begin{array}{l}\text { Water Management (Nov to Mar at } \\
20-25 \text { days interval to ensure good } \\
\text { crop) }\end{array}$ & $\begin{array}{l}120 \\
(83.33)\end{array}$ & $\begin{array}{l}21 \\
(14.58)\end{array}$ & $\begin{array}{l}3 \\
(2.08)\end{array}$ \\
\hline 11 & $\begin{array}{l}\text { Weed Management (Diuron@ @ 2.5-5 } \\
\mathrm{kg} / \mathrm{ha} \text { ) }\end{array}$ & $\begin{array}{l}81 \\
(56.25)\end{array}$ & $\begin{array}{l}63 \\
(43.75)\end{array}$ & $\begin{array}{l}3 \\
(2.08)\end{array}$ \\
\hline 12 & $\begin{array}{l}\text { Insects Pests and Diseases (important } \\
\text { pest was Mealy bug and by applying } \\
\text { ant baits it can be controlled, Heart rot } \\
\text { is important disease in pineapple and } \\
\text { its controlled by foliar application of } \\
\text { fosetyl al ) }\end{array}$ & $\begin{array}{l}141 \\
(97.92\end{array}$ & $\begin{array}{l}3 \\
(2.08)\end{array}$ & $\begin{array}{l}0 \\
(0.00)\end{array}$ \\
\hline
\end{tabular}




\begin{tabular}{|c|c|c|c|c|}
\hline 13 & $\begin{array}{l}\text { Harvesting time and Yield } \\
\text { (Harvested during mid-May to Mid- } \\
\text { July; Yield- } 35000-40000 / \text { ha) }\end{array}$ & $\begin{array}{l}0 \\
(0.00)\end{array}$ & $\begin{array}{l}99 \\
(68.75)\end{array}$ & $\begin{array}{l}45 \\
(31.25)\end{array}$ \\
\hline 14 & $\begin{array}{l}\text { Cleaning (removing the leaves and } \\
\text { stalk from both ends) }\end{array}$ & $\begin{array}{l}39 \\
(27.08)\end{array}$ & $\begin{array}{l}54 \\
(37.50)\end{array}$ & $\begin{array}{l}51 \\
(35.42)\end{array}$ \\
\hline 15 & $\begin{array}{l}\text { Drying (fruits can be kept in the shade } \\
\text { for a short duration) }\end{array}$ & $\begin{array}{l}51 \\
(35.42)\end{array}$ & $\begin{array}{l}54 \\
(37.50)\end{array}$ & $\begin{array}{l}39 \\
(27.08)\end{array}$ \\
\hline 16 & $\begin{array}{l}\text { Grading (fruits can be separated and } \\
\text { graded according to the size) }\end{array}$ & $\begin{array}{l}39 \\
(27.08)\end{array}$ & $\begin{array}{l}48 \\
(33.33)\end{array}$ & $\begin{array}{l}57 \\
(39.58)\end{array}$ \\
\hline 17 & $\begin{array}{l}\text { Packaging and transportation (Clean } \\
\text { bamboo baskets are used for packing) }\end{array}$ & $\begin{array}{l}96 \\
(66.67)\end{array}$ & $\begin{array}{l}33 \\
(22.92)\end{array}$ & $\begin{array}{l}15 \\
(10.42)\end{array}$ \\
\hline 18 & $\begin{array}{l}\text { Storage go down } \\
\begin{array}{l}\text { (ventilation is required for shent } \\
\text { duration storage) }\end{array}\end{array}$ & $\begin{array}{l}120 \\
(83.33)\end{array}$ & $\begin{array}{l}24 \\
(16.67)\end{array}$ & $\begin{array}{l}0 \\
(0.00)\end{array}$ \\
\hline 19 & $\begin{array}{l}\text { Control of storage pest (Rodents, } \\
\text { squirrels, etc) }\end{array}$ & $\begin{array}{l}120 \\
(83.33)\end{array}$ & $\begin{array}{l}24 \\
(16.67)\end{array}$ & $\begin{array}{l}0 \\
(0.00)\end{array}$ \\
\hline
\end{tabular}

Table.3 Constraints faced by the respondents in the management of selected horticultural crop cultivation

\begin{tabular}{|c|c|c|c|c|}
\hline $\begin{array}{l}\text { Sl. } \\
\text { No. }\end{array}$ & Nature of constraints & Frequency & $\%$ & Rank \\
\hline 1. & High pest and disease incidence & 129 & 89.58 & I \\
\hline 2. & $\begin{array}{l}\text { Unavailability of post-harvest storage } \\
\text { facilities }\end{array}$ & 105 & 72.92 & II \\
\hline 3. & $\begin{array}{l}\text { Unavailability of quality planting } \\
\text { materials }\end{array}$ & 75 & 52.08 & III \\
\hline 4. & $\begin{array}{l}\text { Limited help from extension personnel } \\
\text { during crop production }\end{array}$ & 45 & 31.25 & IV \\
\hline 5. & $\begin{array}{l}\text { Unavailability of inputs like fertilizers, } \\
\text { plant protection chemicals, herbicides etc. }\end{array}$ & 15 & 10.42 & V \\
\hline 6. & $\begin{array}{l}\text { Other problems (like unavailability of } \\
\text { water storage structures, electrical facility } \\
\text { etc.) }\end{array}$ & 6 & 4.16 & VI \\
\hline 7. & $\begin{array}{l}\text { Lack of technical knowledge for crop } \\
\text { production }\end{array}$ & 3 & 2.08 & VII \\
\hline 8 & Inadequate loan/credit facility & 3 & 2.08 & VIII \\
\hline
\end{tabular}


Fig 1: Graphical representation of nature of constraints faced by the respondents (\%)

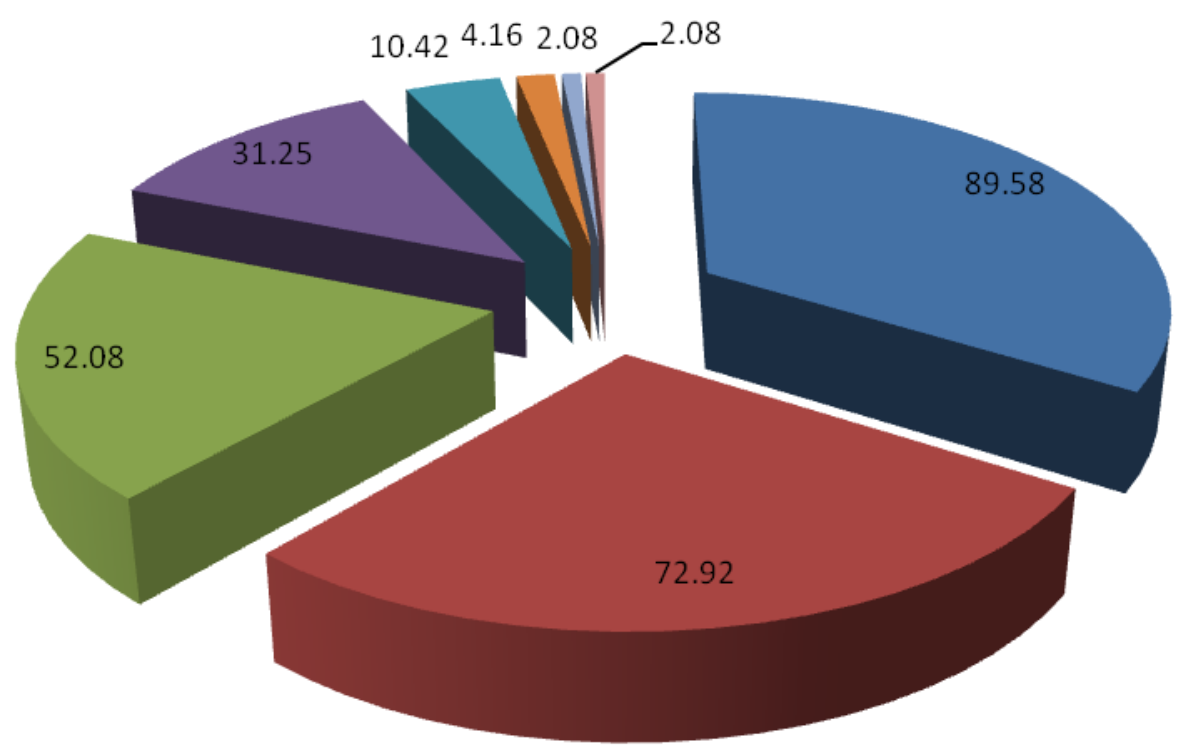

It was also found farmers faced problems like water scarcity during summer, electricity problem. Only few numbers faced problem in lack of technical knowledge during crop production and to get loan in time. This might be due to their low social influence and lack of proper contact with the financial institutions.

Most of the farmers belonged to medium age group and scheduled tribe had education upto secondary school. Nuclear family type and medium family size was found to be the most among the Pineapple farmers. Most of the Pineapple farmers possessed low level of social participation and had income below Rs. 30,000 from pineapple cultivation in a year. Medium extension contact and medium level of information sources utilization also found the most. Further, majority of pineapple growers fully adopted the recommended practices of grading the pineapple fruit. Among the various constraints, high incidence of pest and diseases was found the most.

References
Anonymous.2017. Horticultural Statistics at a Glance 2017. Horticulture Statistics Division, Department of Agriculture,Cooperation\& Farmers Welfare, Ministry of Agriculture \& Farmers Welfare, Government of India Arneja, C.S., Singh, R. andKaur, G. 2009. Constraints in potato cultivation faced by the potato growers.Agricultural Science Digest, 29(2):51-53.

Baruah, R.,Borua, S.,Deka, C.R. and Borah, D.2015.Entrepreneurial behaviour of tribal winter vegetable growers in Jorhat district of Assam.Indian Research Journal of Extension Education, 15(1):65-69.

Baruwa, O. I. 2013. Profitability and constraints of pineapple production in Osun state, Nigeria. Journal of Horticultural Research 21(2): 59-64

Chavai, A.M., Makar, H.B. andBarange, P.K. 
2015.Adoption of potato production technology by the farmers of Maharashtra.Journal of Agriculture Research and Technology, 40(1):9497.

Jaisawal, D.K.,Dubey, M.K. andRajan, P. 2013.Training Need of Vegetable Growers.TECHNOFAME- A Journal of Multidisciplinary Advance Research,2(2):50- 56.

Kafle, B. and Shah, P. 2012. Adoption of improved potato varieties in Nepal: a case of Bara district. The Journal of Agricultural Sciences 7(1): 14-22.

Kotnala, A. andDubey, L.R. 2013.Cropping pattern and production problems of vegetable growers in Nainital district of Uttarakhand.Environment and Ecology, 31(2):496-499.

Kulkarni, N.P. andJahagirdar, K.A. 2015. Technological gap in recommended rose cultivation practices in Dharwad district, Karnataka. Karnataka Journal of Agricultural Sciences 28(3):381384.

Lal, B.,Sinha, T.K., Kumar, A., Pandit, A.,
andPandey, N.K. 2011. Constraints perceived by the farmers in adoption of potato technology. Potato Journal,38(1):73-77.

Nath, D., Biswas, P.K. 2011.Production Constraints of Vegetable Cultivation in West Tripura.Journal of Community Mobilization and Sustainable Development, 6(2):177-179.

Roy, D., Bandyopadhyay, A. K. and Ghosh, A. 2013. Identification of technological gap in pineapplecultivation in some selected areas of West Bengal.International Journal of Science, Environment and Technology 2(3):442 - 448

Singh, P., Choudhary, M. andLakhera, J.P. 2014.Knowledge and attitude of farmers towards improved wheat production technology.Indian Journal of Extension Education, 14(2):54-9.

Wase, R.B. 2001.Knowledge and adoption of farmers about Jayanti chilli cultivation.M.Sc (Agri.) Thesis, Dr.PunjabraoDeshmukh Krishi Vidyalaya, Akola, India.

\section{How to cite this article:}

Rajib Das, Kaushal Kumar Jha, Abhishek Sen and Siraj Miah 2019. Identification of Adoption Gap and Constraints Faced by the Pineapple Growers in the Selected Districts of Tripura. Int.J.Curr.Microbiol.App.Sci. 8(09): 2546-2554. doi: https://doi.org/10.20546/ijcmas.2019.809.295 